\title{
The Effectiveness of Learning to Write Invitation Letters Using Project Based Learning Models and Expository Models for Class V Elementary School Students
}

\author{
Nilawati $^{1}$, Ida Zulaeha ${ }^{2}$, Wagiran ${ }^{3}$ \\ ${ }^{1,2,3}$ Basic Education Study Program, Postgraduate Faculty, State University of Semarang, Central Java, \\ Indonesia \\ Corresponding Author: Nilawati
}

DOI: https://doi.org/10.52403/ijrr.20220132

\begin{abstract}
The aims of this study were (1) to explain the effectiveness of learning to write invitation letters using a project based learning model for fifth grade elementary school students, (2) to explain the effectiveness of learning to write invitation letters using an expository model for fifth grade elementary school students, (3) to find out differences in the level of the effectiveness of learning to write invitation letters with project based learning models and expository models for fifth grade elementary school students. The research designs used in this study were quasi-experiment designs. The results of this study 1) Learning to write invitation letters with a project based learning model had an effect on increasing learning outcomes in writing invitation letters for fifth grade elementary school students, 2) Learning to write invitation letters with an expository model had an effect on increasing learning outcomes in writing invitation letters at fifth grade elementary school students, 3) learning to write invitation letters with an expository model was better than project based learning model learning in improving learning outcomes to write invitation letters for fifth grade elementary school students.
\end{abstract}

Keywords: Learning to write invitation letters, project-based learning models, expository models

\section{INTRODUCTION}

Education is a process in order to influence students to form attitudes and personalities and develop their potential with the aim of making quality as human beings. This is in accordance with Law no. 20 of 2003 concerning the National Education System which states that in developing the potential of students to become human beings who believe and fear God Almighty, have noble character, are healthy, knowledgeable, capable, creative, independent, and become democratic and responsible citizens.

The learning in the 2013 elementary school curriculum is an integrated learning with a scientific approach. Curriculum 2013 learning is carried out using innovative learning models and methods to train and integrate the 4Cs (Creativity and Innovation, Critical Thinking and Problem Solving, Communication, Collaboration), Literacy, HOT, and Strengthening Character Education (Kemendikbud, 2013). Born of the 2013 Curriculum is a government policy in responding to the challenges and demands of the global era. In the 2013 curriculum, increasing competence in the dimensions of affective \& social skills and thinking skills is the main goal achieved through learning that uses a scientific approach and models that familiarize 
students with critical thinking, skills, and noble character (Zulaeha, 2015).

Bahasa is the language of instruction in learning or ongoing learning then Indonesian has an important position in a learning process, because learning Bahasa in elementary schools aimed to improve students' abilities to be able to communicate effectively, both oral and written communication (Lia \& Anggi, 2020). Learning Bahasa is very important as a scientific support in the sense of studying other sciences and Indonesian literature itself, in elementary schools lessons Bahasa are also one of the subjects tested nationally. Thus, Bahasa subjects have a very important role in improving education, both for individuals, communities, as well as the nation and state (Wahyu 2020).

Writing as one of the language skills, needs to get more attention in learning at school. Writing is an activity to express feelings, ideas, ideas, or opinions in writing aimed at other people by paying attention to linguistic rules indirectly (Andira et al, 2017). The writing ability is in the form of an ability about students' creativity in expressing ideas, ideas, feelings and expressions in the form of written language, further other people can easily understand the contents of the writing in the form of clear information (Djuwita, 2017). Writing can be said as an activity of stringing letters into words or sentences to be conveyed to others, so that others can understand them. Dalman (2015: 273) one part of writing skills is writing invitation letters. An invitation letter is a letter sent by a certain person/institution to another institution as a form to fulfill a certain invitation. Invitation letters must follow the rules of correspondence, starting from the structure of the letter, the spelling used and the language of the letter (Fitriani \& Kemal, 2013). Given the importance of letters in communication activities, their writing needs serious attention, both in terms of systematics and language. Letter language must use standard language, namely using good and correct language in accordance with EYD (Enhanced Spelling) rules. In addition, the use of effective sentences must also be a concern so as not to cause double interpretation or misunderstanding of the letter's intent (Andira et al, 2017).

The results of observations, learning in writing informal invitation letters in elementary schools, there was students have difficulty in making invitation letters, especially informal invitation letters, for example, birthday invitation letters. Students still had difficulty in writing invitation letters using effective sentences and correct spelling because teachers often gave assignments in the form of questions only and often used the lecture method which resulted in less activating students in learning, then students were less active in scientific product discovery activities in learning. Through the lecture method and giving questions alone, it is difficult for students to imagine the material being studied and even students could lose concentration, the material presented by the teacher and the books they read were difficult for students to accept. This resulted in the low level of writing invitation letters, so that the learning objectives had not been achieved.

Based on the issue above, a learning process is needed where students are active in exploring their knowledge, students could understand concepts and analyze skills properly and correctly in producing a product or a work. This issue was quite important because this skill must be possessed by students in learning to write invitation letters. Therefore, innovative models, approaches, strategies and methods are needed in the learning process. According to Thomas in (Ademas, 2018) a project-based learning model or projectbased learning was a learning model that involves students in problem-solving activities and other meaningful tasks, giving students opportunities to work autonomously, constructing their own learning activities, and producing student work products. Project based learning $(\mathrm{PjBL})$ is one of the ways of learning by 
using projects as a step to achieve learning objectives (Susilawati, 2018).

According to (Maria, 2015) conveyed that the advantages of the project based learning model included: (1) increased student learning motivation "Many written reports about projects say that students like to persevere until the deadline, try hard in achieving projects, teachers also reported improvement in attendance and reduced tardiness, students reported that learning in projects was more fun than other components of the curriculum", (2) improved problem-solving skills "Research on the development of students' higher-order cognitive skills emphasized the need for students to engage in tasks problem solving tasks and the need for special learning on how to find and solve problems, many sources describe projectbased learning environments make students more active and successfully solve complex problems", (3) increased collaboration "the importance of group work in projects requires student develop and practice communication skills, cooperative group work, student evaluation, exchange of information", (4) improved resource management skills "part of being an independent student is being responsible for completing complex tasks, well implemented providing students with learning and practice in organizing projects and allocate time and other resources such as equipment to complete tasks".

In addition to having advantages, the project-based learning model also has disadvantages. The disadvantage of the project-based learning model according to Sani in (Zulhana, 2017) were : (1) it took a lot of time to solve problems and produce products, (2) required sufficient costs, (3) required skilled and willing teachers to learn, (4) required adequate facilities, equipment, and materials, (5) were not suitable for students who give up easily and do not have the knowledge and skills needed, (6) difficulty involving all students in group work. According to the Ministry of Education and Culture (2014: 34), the steps for project-based learning can be explained here: Determining basic questions, developing project plans, Preparing project implementation schedules, Monitoring, Assessment of results, Evaluation of experiences.

In addition to using the PJBL model, this research also uses an expository learning model. The expository model is a learning method used by providing information on the definitions, principles and concepts of the subject matter as well as providing examples of problem-solving exercises in the form of lectures, demonstrations, questions and answers and assignments (Wakiyem, 2017). Sanjaya in (Setiawan, 2017) stated expository learning model is a learning model that emphasizes the process of delivering material verbally from a teacher to a group of students with the intention that students can master the subject matter optimally.

According to Tuti (2017) the characteristics of the expository model included: (1) the expository strategy is carried out by conveying the main material in carrying out this strategy, therefore people often identify it with the lecture method; (2) usually ready-made material, such as data or facts, certain concepts that must be memorized so that they do not require students to think again; (3) the main purpose of learning is mastery of the subject matter itself, meaning that after learning ends students are expected to understand it properly and correctly by being able to re-express the material that has been described.

According to Afnan (2018) there were several steps in the application of the expository model, namely: preparation, presentation, correlation, concluding, applying.

According to (Gestiana et al, 2020) the expository model had several advantages, including: 1) by using expository learning the teacher can control or check the order and mastery of learning material, thus he can find out to what extent students understand the material, 2) expository learning is considered very 
effective in the learning process at school, 3) expository learning besides being effective can also make students listen more to the subject matter, it also makes students able to see or observe the material presented by the teacher. According to (Gestiana et al, 2020) said the expository model has weaknesses, including the following; 1 ) this learning is not possible to see the overall difference in the learning character of each individual, both differences in abilities, differences in knowledge, interests, and talents, as well as differences in student learning styles, 2) expository learning is mostly given through lectures or teacher explanations, making it difficult to develop abilities students in terms of the ability to socialize interpersonal relationships between students in the environment.

\section{METHOD}

The method of this study used a research design that was quasi experimental designs. In this study, there were two independent variables and 1 dependent variable, there were the independent variable (X1) using the project-based learning model, the independent variable (X2) using the expository model, and the dependent variable $(\mathrm{Y})$ learning to write invitation letters. The population of this research was the fifth-grade elementary school students in the 2021/2022 academic year. The sample in this study was the ability to learn to write invitation letters in class $\mathrm{V}$ at SDN Gabus 01 and SDN Tanjunganom 02 .

The data collection techniques used in this study were tests and observations. The test technique was used to gain scores, both for the experimental group 1 with the project-based learning model and the experimental group 2 with the expository model. Observation techniques used to determine the activities of students when receiving learning. The instrument validation here used content and construct validity. The data analysis technique used the normality test was used to determine whether the two groups were normally distributed or not, the technique used to test for normality was the One Sample Kolmogorov-Smirnov Test analysis using SPSS. The homogeneity test was carried out to obtain the assumption that the research sample started from the same conditions or homogeneous, which in turn was to determine the $\mathrm{t}$ statistic to be used in hypothesis testing. Homogeneity test is done by investigating whether the two samples have the same variance or not. The hypothesis test used to analyze this research is using the $t$ test with the help of the SPSS program. The hypotheses in this study are as follows:

\section{RESULT \& DISCUSSION}

The results showed that the average value of the initial test for the project based learning class was 54.21, the highest score was 71 and the lowest score was 35 . The average value for the expository class was 50.19 , the highest score was 63 and the lowest score was 37 . The average test score the end of the project based learning class was 80.82 and the average value of the expository class final test was 84.26.

\begin{tabular}{|l|l|l|l|}
\hline Learning Model & Pre-Test & Pos-Test & Average \\
\hline Project Based Learning & 54.21 & 80.82 & 26.61 \\
\hline Expository & 50.19 & 84.26 & 34.07 \\
\hline
\end{tabular}

Before the data was analyzed, the analysis requirements were first tested, there were the normality test and homogeneity test. The results of the calculation of the normality test of experiment 1 using the Project Based Learning model were:

\begin{tabular}{|l|l|l|l|l|l|l|}
\hline Tests of Normality & Kolmogorov-Smirnov \\
\hline & Statistic & df & Shapiro- & Statistic & df & Sig. \\
\hline & .166 & 28 & .048 & .907 & 28 & .017 \\
\hline PreTestEksperimen1 & .150 & 28 & .105 & .956 & 28 & .285 \\
\hline PostTestEksperimen1 & \multicolumn{7}{|c|}{ Lilliefors Significance Correction }
\end{tabular}


Normality test was performed using the Kolmogorov Smirnov test with a significance level of $5 \%(\alpha=0.05)$. If the $p$ value $>0.05$ then the data is normally distributed, if $\mathrm{p}<0.05$ then the data is declared not normally distributed. Based on the results of the normality test of the data in experiment 1 above, it can be seen that the LPL value in the pretest 1 was 10.48 and the 1 posttest was 10.105 . Based on the test results, it can be concluded that the two groups of data in experiment 1 were normally distributed.

The results of the calculation of the normality test of experiment 2 using the expository model were:

\begin{tabular}{|l|l|l|l|l|l|l|}
\hline Tests of Normality & \multicolumn{9}{|l|}{ Kolmogorov-Smirnov } & \multicolumn{3}{|l|}{ Shapiro-Wilk } \\
\hline & Statistic & df & Sig. & Statistic & df & Sig. \\
\hline PreTestEksperimen2 & .195 & 27 & .010 & .885 & 27 & .006 \\
\hline PostTestEksperimen2 & .168 & 27 & .048 & .948 & 27 & .191 \\
\hline Lilliefors Significance Correction \\
\hline
\end{tabular}

Based on the results of the normality test of the data in experiment 1 above, it can be seen that the value of LPL in the pretest was 10.10 and at the posttest, it was 10.48 .
Based on the test results, it can be concluded that the two groups of data in experiment 2 are normally distributed

\begin{tabular}{|c|c|c|c|c|c|}
\hline \multicolumn{6}{|c|}{ Test of Homogeneity of Variances } \\
\hline & & Levene Statistic & df1 & df2 & Sig. \\
\hline \multirow{4}{*}{ Experiment Result } & Based on Mean & 2.589 & 1 & 108 & .111 \\
\hline & Based on Median & 3.378 & 1 & 108 & .069 \\
\hline & Based on Median and with adjusted df & 3.378 & 1 & 90.739 & .069 \\
\hline & Based on trimmed mean & 2.779 & 1 & 108 & .098 \\
\hline
\end{tabular}

Homogeneity test is a test of whether or not the variances of two or more distributions are equal. The data is declared homogeneous if the value of Sig. > 0.05. Based on the results of the homogeneity test of experimental data 1 and 2, the p-value is 0.111 . This meant that the two data were homogeneously distributed
Based on the results of the data above, then the data were analyzed by t test. The t-test was used to determine the difference in the learning outcomes of writing invitation letters with the Project Based Learning model and the expository model. The following are the results of the $t$ test:

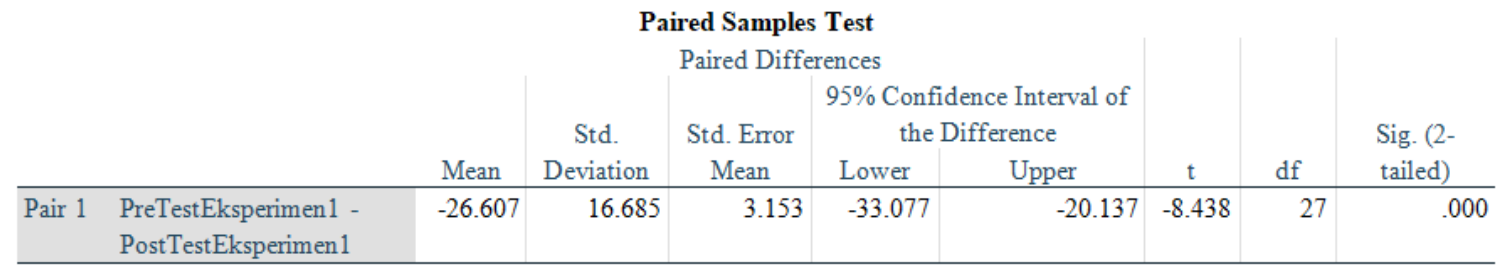

Because the paired sample $\mathrm{t}$ test results show probability (Sig. 2 tailed) $=$ $0.000<0.05$, it is decided that $\mathrm{HO}$ is rejected. it can be concluded that there are differences in the level of learning ability to write invitation letters before and after the application of the project based learning model.

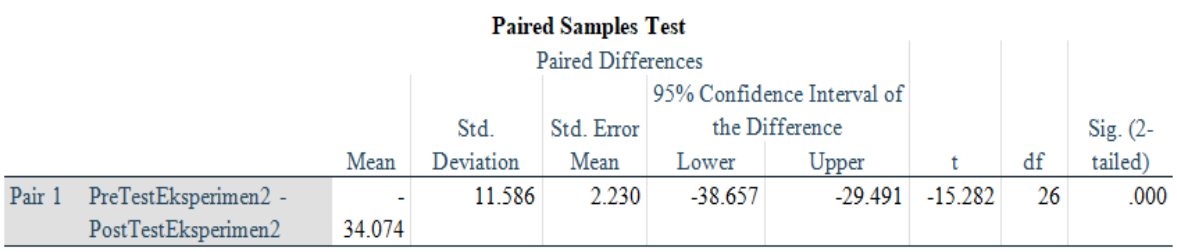


Because the paired sample $\mathrm{t}$ test results show probability (Sig. 2 tailed) $=$ $0.000<0.05$, it decided that $\mathrm{H} 0$ is rejected. With this, it can be concluded that there were differences in the level of ability in learning to write invitation letters before and after the application of the expository model.

The results of calculations with SPSS, learning to write invitation letters with the expository model was more effectively applied to students. This is proved by the results of the $\mathrm{t}$-test obtained a significance value of $0.000<0.05$. In addition, it is proven by an average of 84.26 $<80.82$.

\section{Improving Learning Outcomes in Writing Invitation Letters}

The analysis of the increase in learning outcomes to write invitation letters was carried out to find out how much treatment in the experimental group 1 and in the experimental group 2 was able to improve the results of learning to write invitation letters. The results of the calculation of the increase in learning outcomes to write invitation letters can be seen in the table below.

Table of Improving Learning Outcomes in Writing Invitation Letters

\begin{tabular}{|l|l|l|l|l|}
\hline \multirow{2}{*}{ Group } & \multicolumn{2}{|c|}{ Average value } & Enhancement & \% Enhancement \\
\cline { 2 - 5 } & Pre-Test & Pos-Test & Pretest- Posttest & Pretest- Posttest \\
\hline Experiment 1 & 54,21 & 80,82 & 26,61 & $49,08 \%$ \\
\hline Experiment 2 & 50,19 & 84,26 & 34,07 & $67,90 \%$ \\
\hline
\end{tabular}

From the table above, it is obtained information on the percentage increase in learning outcomes to write invitation letters for experimental group 1, namely the group that was given learning to write invitation letters with a project based learning model of $49.08 \%$ and the percentage increase in learning outcomes to write invitation letters for experimental group 2 who were given writing lessons. invitation letter with expository model of $67.90 \%$.

\section{CONCLUSION}

Based on the results of the research and discussion that had presented, the following conclusions can be shown: 1) Learning to write invitation letters with a project based learning model had an effect on increasing learning outcomes in writing invitation letters for fifth grade elementary school students, 2) Learning to write invitation letters with an expository model had an effect on increasing learning outcomes to write invitation letters for fifth grade elementary school students, 3) learning to write invitation letters with expository models was better than projectbased learning model learning in improving learning outcomes of writing invitation letters for fifth grade elementary school students.

\section{Acknowledgement: None}

Conflict of Interest: None

\section{Source of Funding: None}

\section{REFERENCES}

1. Ida Zulaeha. 2013. "Pengembangan Model Pembelajaran Keterampilan Berbahasa Indonesia Berkonteks Multikultural”. FBS Universitas Negeri Semarang, Volume 12 Nomor 1.

2. Wahyu Bagja Sulfemi, Siswanto, Toni Heryadi, Anggun Nurfitria Soleh. 2020. "Model Project Based Learning Berbantu Media Kartu dalam Pembelajaran Bahasa Indonesia Materi Kalimat Efektif pada Surat Undangan". Depok, Volume 18 Nmoror 2.

3. Febri Andira, Adnan, M. Yamin. 2017. "Kemampuan Menulis Surat Resmi Siswa Kelas V SD Negeri Garot Aceh Besar". Jurnal Ilmiah Pendidikan Guru Sekolah Dasar, Volume 2 Nomor 1.

4. Ademas Dwi Laksono. 2018. "Keefektifan Model Project Based Learning terhadap Keaktifandan Hasil Belajar IPA Kelas V SDN Sumberejo 2 Bonang". Universitas PGRI Semarang, Volume 2 Nomor 2. 
5. Dalman. 2015. Keterampilan Menulis. Jakarta: PT Rajagrafindo Persada.

6. Susilawati, Widia Nur Jannah, Dianasari. 2019. "Efektivitas Project Based Learning Terhadap Keterampilan Menulis Bahan Ajar IPA Calon Guru SD". Universitas Muhammadiyah Cirebon, Volume 10 Nomor 1.

7. Maria Anita Titu. 2015. "Penerapan Model Pembelajaran Project Based Learning (PJBL) untuk Meningkatkan Kreativitas Siswa pada Materi Konsep Masalah Ekonomi”. Prosiding Seminar Nasional Hlm 176-186.

8. Ayu Hartini. 2017. "Pengembangan Perangkat Pembelajaran Model Project Based Learning untuk Meningkatkan Kemampuan Berpikir Kritis Siswa Sekolah Dasar". Jurnal Pendidikan dan Pembelajaran Sekolah Dasar, Volume 1 Nomor 2a.

9. Triani Lailatunnahar. 2021. "Penerapan Metode Pembelajaran Project Based Learning Guna Meningkatkan Hasil Belajar IPA Di Masa Pandemi Covid 19 pada Siswa Kelas VII 1 di SMP Negeri Binaan Khusus
Kota Dumai”. Jurnal Pendidikan Tambusai, Volume 5 Nomor 1.

10. Angga Risnaini Uswatun Chasanah, Nur Khoiri, Harto Nuroso. 2016. "Efektivitas Model Project Based Learning terhadap Keterampilan Proses Sains dan Kemampuan Berpikir Kreatif Siswa pada Pokok Bahasan Kalor Kelas X SMAN 1 Wonosegoro Tahun Pelajaran 2014/2015". Jurnal Penelitian Pembelajaran Fisika, Volume 7 Hlm 19-24.

11. Winda Malfani, Melva Zainil. 2020. "Penerapan Model Project Based Learning (PJBL) Terhadap Hasil Belajar Matematika di SD". Journal of Basic Education Studies, Volume 3 Nomor 2.

How to cite this article: Nilawati, Ida Zulaeha, Wagiran. The effectiveness of learning to write invitation letters using project based learning models and expository models for class $\mathrm{V}$ elementary school students. International Journal of Research and Review. 2022; 9(1): 269-275. DOI: https://doi.org/10.52403/ijrr. 20220132 